\title{
MASTER
}

\section{ANALYSIS OF INVERTEBRATE POPULATIONS INHABITING THE SHRUB-STEPPE \\ REGION OF SOUTHCENTRAL WASHINGTON (HANFORD RESERVATION)}

Lee E. Rogers

Ecosystems Department

Battelle, Pacific Northwest Laboratories

P. 0. Box 999

Richland, Washington 99352

This report was prepared as an account of work
sponsored by the United States Government. Neither the
United States nor the United States Department of
Energy, nor any of their employees, nor any of their
contractors, subcontractors, or their employees, makes
any warranty, express or implied, or assumes any legal
liability or responsibility for the accuracy, completeness
or usefulness of any information, apparatus, product or
process disclosed, or represents that its use would not
infringe privately owned rights.

DISTRIBUTICA GE I IIS DOCUMENT IS UNLIMIT \&

PREPARED FOR THE U.S. DEPARTMENT OF

FNERGY UNDER CONTRACT EY-76-C-06-1830 


\section{DISCLAIMER}

This report was prepared as an account of work sponsored by an agency of the United States Government. Neither the United States Government nor any agency Thereof, nor any of their employees, makes any warranty, express or implied, or assumes any legal liability or responsibility for the accuracy, completeness, or usefulness of any information, apparatus, product, or process disclosed, or represents that its use would not infringe privately owned rights. Reference herein to any specific commercial product, process, or service by trade name, trademark, manufacturer, or otherwise does not necessarily constitute or imply its endorsement, recommendation, or favoring by the United States Government or any agency thereof. The views and opinions of authors expressed herein do not necessarily state or reflect those of the United States Government or any agency thereof. 


\section{DISCLAIMER}

Portions of this document may be illegible in electronic image products. Images are produced from the best available original document. 


\section{ANALYSIS OF INVERTEBRATE POPULATIONS INHABITING THE SHRUB-STEPPE - REGION OF SOUTHCENTRAL WASHINGTON (HANFORD RESERVATION)}

\section{ABSTRACT}

Field sampling and analytical techniques are described for quantitative shrub-steppe invertebrate ecology studies on the Hanford Reservation. A quick trap, D-vac sampling method followed by Berlese extraction is employed. Computer summarization of results permits presentation of data in terms of density $\left(\mathrm{no} . / \mathrm{m}^{2}\right)$ and biomass $\left(\mathrm{g} / \mathrm{m}^{2}\right)$ for trophic, taxonomic, lifestage and total invertebrate groupings. 
INTRODUCTION

Invertebrates are not a conspicuous component of most grassland regions and their influence is generally not appreciated until an outbreak occurs for pest species such as grasshoppers or range land caterpillars. They are, however, always present, occurring in the soil, within grass tussocks and associated with shrub canopies.

A variety of techniques have been developed for invertebrate sampling-sweep net, pitfall trap, direct counts, hand collecting. These techniques are especially useful when studying specific invertebrate taxa, grasshoppers, flies, ants, etc., but they are not adaptable to providing quantitative sampling estimates for all invertebrate fauna. The purpose of this presentation is to describe techniques used to quantitatively sample and analyze aboveground invertebrate populations inhabiting a semi-arid region in southcentral Washington.

These studies were conducted on the Hanford Reservation which is located near the confluence of the Columbia, Snake and Yakima Rivers. The Reservation occupies about 540 square miles of shrub-steppe vegetation. Approximately 120 square miles of the Reservation has been designated as the Arid Lands Ecology (ALE) Reserve. The studies described here were conducted within the confines of the ALE Reserve. The actual study sites were located within a pristine sagebrush/bunchgrass (Artemisia tridenta/Agropyron spicatum) community and on an old field dominated by cheatgrass (Bromus tectorum). 
METHODS

Sampling

A quick-trap $\left(0.5 \mathrm{~m}^{2}\right)$ was employed to collect samples from the old-field location. The traps were set the day prior to sampling. A long cord permitted remote release of the screen covered cage. Large flying insects were removed by hand or with the aid of a small aspirator. All vegetation within the cage was clipped and placed in a plastic bag. A D-vac aparatus was used to vacuum the soil, removing all litter and associated small invertebrates. These materials were taken to the laboratory, placed in a Berlese funnel and extracted into ethyl alcohol. Extracted samples were sorted beneath a variable power microscope. All specimens were identified, measured to the nearest $0.1 \mathrm{~mm}$ and recorded on a data form.

Similar procedures were followed for the sagebrush/bunchgrass community except that a stratified sampling plan was employed. Separate samples were collected for invertebrates associated with bunchgrass, sagebrush, bare areas and for large flying insects. The $0.5 \mathrm{~m}^{2}$ drop trap was used to collect flying insect and sagebrush samples. Bunchgrass samples were collected by placing a coring tool over selected grass tussocks and extracting a $0.01 \mathrm{~m}^{2}$ core of crown, stem and leaf material. Bare samples were collected by D-vacing selected $0.1 \mathrm{~m}^{2}$ areas located in the open spaces between shrubs and grass tussocks.

Analysis

A data processing flow diagram is shown in Figure 1 depicting computer processing sequences. The data cards contain sampling and analytical information such as: 
- Date

- Treatment

- Replicate

- Sample quadrat

- Sample size $\left(m^{2}\right)$

- Sample strata

- Taxonomic identification

- Number of individuals

- Life stage

- Trophic level

- Size (length in mm)

Biomass data (mg dry weight) may be entered into the data set via one of three pathways: 1) actual weights for individual organisms may be recorded on the data cards, 2) weights may be calculated from length/weight equations developed for shrub-steppe invertebrates (Rogers et al., 1976, 1977) or 3) weights may be obtained from a table of reference weights.

Obtaining weights for individuals is a time consuming process. At the very least weights should be obtained by size groupings for individual taxa on each sample date. This is not practical for most situations and I have only recorded direct weights for unique speciments where length/weight equations did not apply and reference weights were not available.

Most of the biomass data is calculated from length/weight equations. Taxa specific equations were used for common shrub-steppe inhabitants (Table 1). A general length/weight relationship is used for most other taxa (Rogers et a]., 1976). 
The use of length/weight equations for biomass estimation is possible since size data was recorded for all sample specimens. This too is time consuming but consumer size is an ecological parameter that has been largely ignored in the past and consumer size distributions should be documented for shrub-steppe invertebrate populations. In many cases where organisms are of a fairly uniform size throughout the population and over the season a weight reference table is a viable alternative and represents the least labor intensive method for biomass estimation. For example, all Caligonellid (family caligonellidae) mites weigh about $1 \mu \mathrm{g}$. It probably really doesn't matter if some are only $0.5 \mu \mathrm{g}$ and others $1.5 \mu \mathrm{g}$, unless a calligonellid mite population study is being conducted. A table look up would adequately estimate their biomass values.

A first pass computer analysis is made following creation of the data tape to check data coding. This checks trophic level, life stage and taxonomic codes against a list of legitimate codes. After correction of any discrepancies density and biomass values are calculated on a unit area basis $\left(m^{2}\right)$. These data may be summarized for various treatments for any combination of the following options:

- A11 invertebrates

- Trophic leve1

- Order

- Family

- Species

- Lifestage

Estimated density and biomass values are calculated for invertebrate taxa inhabiting each of the sampled shrub-steppe habitat types--sagebrush, 
bunchgrass, bare or flying. These values are then adjusted based on the relative cover and area of sampling tool according to the formula:

$$
\begin{aligned}
& x_{c}=\frac{P_{1} x_{1}+P_{2} x_{2}}{2} \\
& S E_{c}{ }^{2}=P_{1} S_{1}{ }^{2}+P_{2} S E_{2}{ }^{2} \\
& N_{c}=\frac{\left(P_{1}{ }^{2} S E_{1}{ }^{2}+P_{2}{ }^{2} S E_{2}{ }^{2}\right)^{2}}{\frac{P_{1}{ }^{4} S E_{1}{ }^{4}}{N_{1}-1}+\frac{P_{2}{ }^{4} S E_{2}{ }^{4}}{N_{2}-1}}
\end{aligned}
$$

where:

$$
\begin{aligned}
& X_{c}=\text { mean density (or biomass) for combined strata } \\
& X_{1}=\text { mean density (or biomass) for AGSP + BARE + FLY strata } \\
& X_{2}=\text { mean density (or biomass L for ARTR stratum } \\
& P_{1}=\text { percent cover for AGSP + BARE + FLY strata } \\
& P_{2}=\text { percent cover for ARTR stratum } \\
& S_{C}=\text { standard error for combined strata } \\
& { }_{S E}=\text { standard error for AGSP + BARE + FLY strata } \\
& S_{2}=\text { standard error for ARTR stratum } \\
& N_{C}=\text { effective number of quadrats for combined strata } \\
& N_{1}=\text { number of quadrats in combined AGSP + BARE + FLY strata } \\
& N_{2}=\text { number of quadrats in ARTR stratum }
\end{aligned}
$$

0ld field samples represent a single habitat type and do not require this integrating procedure. 


\section{RESULTS}

Estimated density, biomass and associated standard error values for oldfield invertebrates are shown in Table 2 as an example of results. A graphical representation showing the seasonal distribution of density and biomass values is illustrated in figure 2. Maximum density and biomass occurred early in the season followed by a steady decline into summer months. This follows the live plant biomass trend. Peak plant biomass occurs during April or May for green vegetation and declines with the onset of summer drought conditions.

The estimated total invertebrate density and biomass values for the sagebrush/bunchgrass community are shown in Table 3. Density and biomass values are used to compare the relative standings for invertebrate taxa in Figure 3 and Figure 4. Hymenoptera (ants), Hemiptera/Homoptera (bugs) and Acari (mites) were important taxa in terms of density values; however, Lepidoptera (moths), Diptera (flies) and Coleoptera (beetles) were important biomass contributors.

A comparison of taxonomic distribtuion values based on invertebrate densities is shown in Table 4 for grazed, ungrazed and old-field study areas. Important differences occurred for Homoptera (bugs), Coleoptera (beetles) and Thysanoptera (thrips). Homoptera were abundant under grazed and ungrazed conditions but poorly represented in the old-field. The Homoptera were comprised mostly of pseudococcidae (mealy bugs). This family is apparently closely associated with bluebunch wheatgrass and not cheatgrass. Thysanoptera were the third largest contributor in terms of invertebrate density on the old-field but were negligible contributors for the grazed and ungrazed conditions. They are small phytophagous insects that occur in flower heads 
of various plants and are probably associated with cheatgrass on the oldfield. Most of the beetle density was associated with one family, the Tenebrionidae or darkling beetles. Darkling beetles were most abundant during the months of May and June with 54 and 34 individuals per $\mathrm{m}^{2}$ on the old-field, mostly larvae.

An analysis of the trophic distribution of invertebrate density is shown in Table 5. The herbivore and omnivore groups were the two most important trophic levels in all treatment areas. Fungivores were less abundant in the old-field due to a paucity of cryptostigmatid mites.

\section{DISCUSSION}

The concern for preservation of a quality environment coupled with the ever-growing demand for greater levels of energy production have served to focus attention on the need to understand the role of native biota in ecosystem functioning. Invertebrates comprise a significant portion of the consumer component wherever detailed studies have been conducted. Accurate estimates of their density and biomass values are required when attempting to assess their influence on energy flow patterns, mineral cycling or possible destructive impact of invertebrates on natural areas. Few attempts have been made to conduct such studies--primarily I feel--due to difficulties associated with sample collection, taxonomic identification and data analysis. Hopefully this over-view of invertebrate sampling methodology at Hanford will assist in the planning of detailed quantitative invertebrate studies at other NERP installations. 
ACKNOWLEDGMENTS

This paper is based on work supported under Energy Research and Developmont Administration Contract $E(45-1)-1830$. The basic computer analysis program was developed as part of the International Biological Grasslands Biome Program. Thanks are extended to the biome director and especially to Vicki Keith for making this program available to us. Special thanks are also extended to Chuck Watson, Paul Tucker, Jim MacIntyre and Jessie Burns for help in adapting the computer program to our needs. 


\section{REFERENCES}

Rogers, L. E., R. L. Buschbom and C. R. Watson. 1977. Length-Weight Relationships for Shrub-Steppe Invertebrates. Ann. Entomol. Soc. Am. 70: $51-5$.

Rogers, L. E., W. T. Hinds and R. L. Buschbom. 1976. A General Weight vs Length Relationship for Insects. Ann. Entomol. Soc. Am. 69: 387-9. 
TABLE 1. Parameter estimates for length-weight equations (Rogers et al., 1977)

\begin{tabular}{llcccc}
\hline Taxa & Lifestage & Model & $\mathrm{B}_{\mathrm{O}} \pm \mathrm{SE}$ & $\mathrm{B}_{1} \pm \mathrm{SE}$ & $\mathrm{r}$ \\
\hline Coleoptera & $\mathrm{A}$ & 1 & $-3.460 \pm 0.105$ & $2.790 \pm 0.050$ & 0.98 \\
$\quad$ Tenebrionidae & $\mathrm{A}$ & 1 & $-3.050 \pm 0.204$ & $2.681 \pm 0.080$ & 0.97 \\
Curculionidae & $\mathrm{A}$ & 1 & $-3.915 \pm 0.245$ & $3.050 \pm 0.164$ & 0.98 \\
Coleoptera & $\mathrm{L}$ & 3 & $-0.792 \pm 0.652$ & $0.571 \pm 0.055$ & 0.80 \\
Tenebrionidae & $\mathrm{L}$ & 2 & $-2.461 \pm 0.493$ & $0.216 \pm 0.028$ & 0.84 \\
Curculionidae & $\mathrm{L}$ & 1 & $-1.268 \pm 0.361$ & $0.912 \pm 0.115$ & 0.86 \\
Diptera & $\mathrm{A}$ & 1 & $-3.293 \pm 0.115$ & $2.366 \pm 0.078$ & 0.96 \\
Diptera & $\mathrm{L}$ & 2 & $-3.731 \pm 0.472$ & $0.356 \pm 0.051$ & 0.87 \\
Lepidoptera & $\mathrm{A}$ & 1 & $-4.037 \pm 0.133$ & $2.903 \pm 0.080$ & 0.99 \\
Lepidoptera & $\mathrm{L}$ & 1 & $-5.137 \pm 0.319$ & $2.809 \pm 0.146$ & 0.97 \\
Hemiptera & $\mathrm{A} / \mathrm{N}$ & 1 & $-2.998 \pm 0.113$ & $2.270 \pm 0.081$ & 0.98 \\
Homoptera & $\mathrm{A} / \mathrm{N}$ & 1 & $-3.308 \pm 0.062$ & $2.696 \pm 0.046$ & 0.99 \\
Combined & $\mathrm{A} / \mathrm{N}$ & 1 & $-3.243 \pm 0.062$ & $2.566 \pm 0.045$ & 0.99 \\
$\quad$ Pseudococcidae & $\mathrm{A} / \mathrm{N}$ & 1 & $-4.094 \pm 0.164$ & $2.626 \pm 0.501$ & 0.83 \\
Hymenoptera & $\mathrm{A}$ & 1 & $-3.871 \pm 0.108$ & $2.407 \pm 0.060$ & 0.97 \\
Formicidae & $\mathrm{A}$ & 1 & $-4.029 \pm 0.171$ & $2.572 \pm 0.097$ & 0.98 \\
Acarina & $\mathrm{A} / \mathrm{N}$ & 1 & $+3.682 \pm 0.171$ & $2.761 \pm 0.309$ & 0.85 \\
Crytostigmata & $\mathrm{A} / \mathrm{N}$ & 1 & $+3.944 \pm 0.103$ & $2.790 \pm 0.207$ & 0.95 \\
Prostigmata and & & & & & \\
$\quad$ Astigmata & $\mathrm{A} / \mathrm{N}$ & 1 & $+2.897 \pm 0.312$ & $2.210 \pm 0.479$ & 0.84 \\
Orthoptera & $\mathrm{A} / \mathrm{N}$ & 1 & $-3.020 \pm 0.284$ & $2.515 \pm 0.105$ & 0.97 \\
Araneida & $\mathrm{A} / \mathrm{N}$ & 1 & $-3.106 \pm 0.189$ & $2.929 \pm 0.294$ & 0.90 \\
& & & & &
\end{tabular}


TABLE 2. Estimated old-field invertebrate density and biomass values

\begin{tabular}{lrr}
\hline Date & Density $^{\top}$ & Biomass $^{2}$ \\
\hline Apri1 & $292 \pm 106$ & $125 \pm 33$ \\
May & $224 \pm 49$ & $300 \pm 123$ \\
June & $96 \pm 18$ & $260 \pm 75$ \\
July & $16 \pm 7$ & $193 \pm 68$ \\
August & $12 \pm 3$ & $2 \pm 2$ \\
& &
\end{tabular}

Density $=$ number $/ \mathrm{m}^{2}$

2 Biomass $=\mathrm{mg} \mathrm{dry} / \mathrm{m}^{2}$ 
TABLE 3. Estimated total invertebrate density and biomass values for the sagebrush/bunchgrass community.

\begin{tabular}{lrl}
\hline Month & Density & Biomass \\
\hline March & $693 \pm 113$ & $170 \pm 53$ \\
Apri1 & $1895 \pm 856$ & $215 \pm 86$ \\
May & $960 \pm 317$ & $278 \pm 92$ \\
June & $559 \pm 133$ & $191 \pm 55$ \\
July & $446 \pm 117$ & $451 \pm 187$ \\
August & $515 \pm 207$ & $392 \pm 140$ \\
\hline
\end{tabular}

1 Biomass expressed as $\mathrm{mg} / \mathrm{m}^{2}$ dry weight 
TABLE 4. Taxonomic distribution (\%) in grazed, ungrazed and old field study areas based on invertebrate density

\begin{tabular}{lccc}
\hline Order & Ungrazed & Grazed & 0ld field \\
\hline Acari & 48 & 38 & 37 \\
Hymenoptera & 24 & 17 & 8 \\
Homptera & 14 & 26 & 1 \\
Diptera & 3 & 3 & 4 \\
Coleoptera & 3 & 3 & 18 \\
Lepidoptera & 2 & 2 & $<1$ \\
Psocoptera & 1 & 2 & 7 \\
Araneida & 1 & 1 & 1 \\
Collembola & 1 & 1 & 0 \\
Thysanoptera & 1 & 1 & 15 \\
Thysanura & 1 & $<1$ & 0 \\
Hemiptera & 1 & 6 & 8 \\
Isoptera & $<1$ & $<1$ & 0 \\
Neuroptera & $<1$ & $<1$ & 0 \\
Orthoptera & $<1$ & $<1$ & 1 \\
Solpugida & $<1$ & 0 & 0 \\
Geophilomorpha & 0 & & $<1$ \\
\hline
\end{tabular}


TABLE 5. Trophic distribution (\%) in grazed, ungrazed and old field study areas based on invertebrate density

\begin{tabular}{|c|c|c|c|}
\hline Trophic Level & $\begin{array}{l}\text { Ungrazed } \\
-\end{array}$ & $\begin{array}{l}\text { Grazed } \\
-\%--\end{array}$ & old Field \\
\hline Herbivore & 27 & 42 & 56 \\
\hline Tissue & 7 & 6 & 28 \\
\hline Sap & 17 & 32 & 24 \\
\hline Pollen and Nector & 3 & 4 & 4 \\
\hline Predator & 23 & 20 & 8 \\
\hline Omnivore & 29 & 23 & 34 \\
\hline Fungivore & 19 & 14 & $<1$ \\
\hline Unknown & 2 & 1 & $<1$ \\
\hline
\end{tabular}


FIGURE 1. Data Processing Flow Diagram

FIGURE 2. Estimated 01d Field Biomass and Density Values

FIGURE 3. Seasonal Distribution of "Taxa:Biomass:

FIGURE 4. Seasonal Distribution of Taxonomic Density 
11

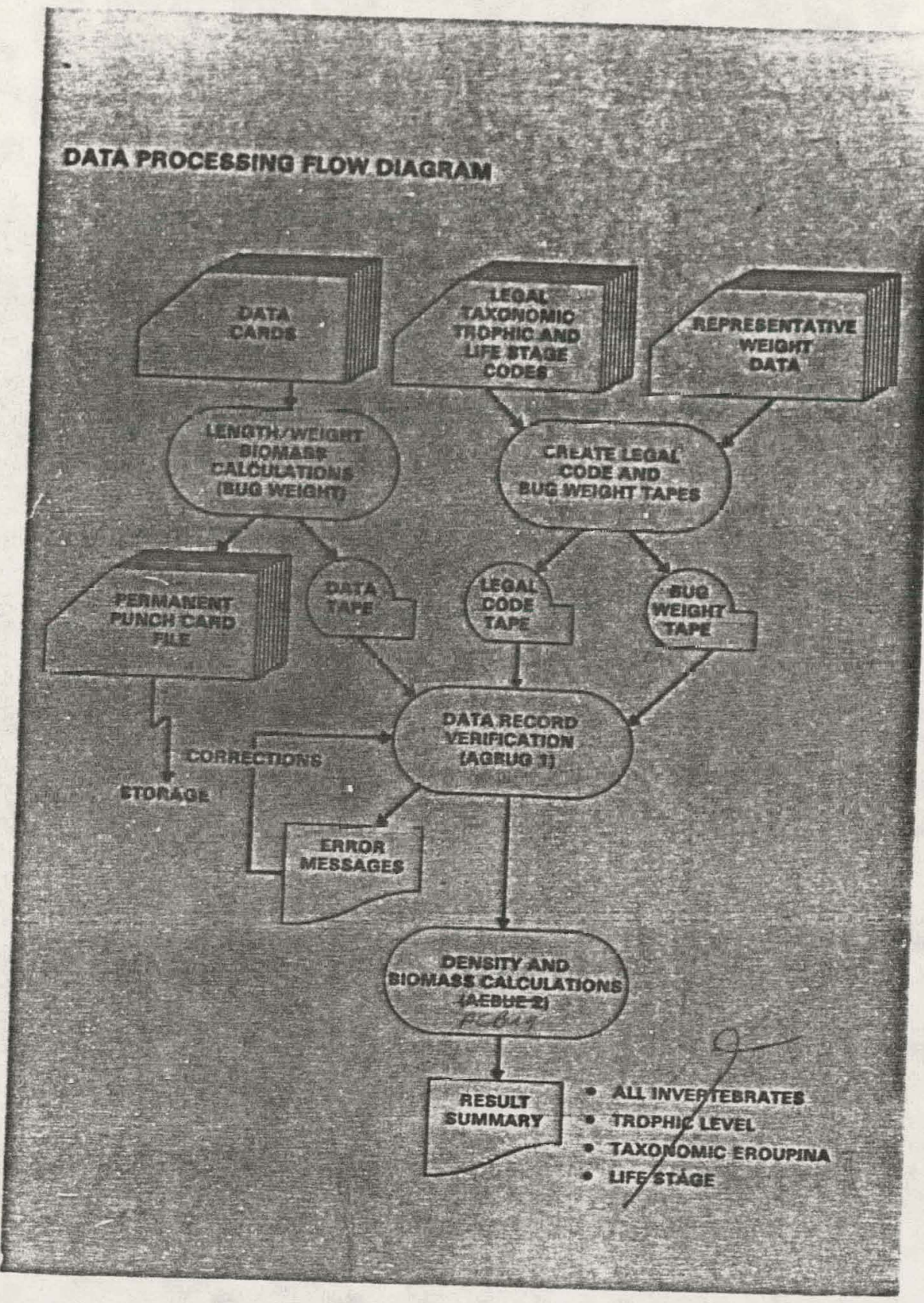




\section{INVERTEBRATE}

DENSITY AND BIOMASS OLDFIELD

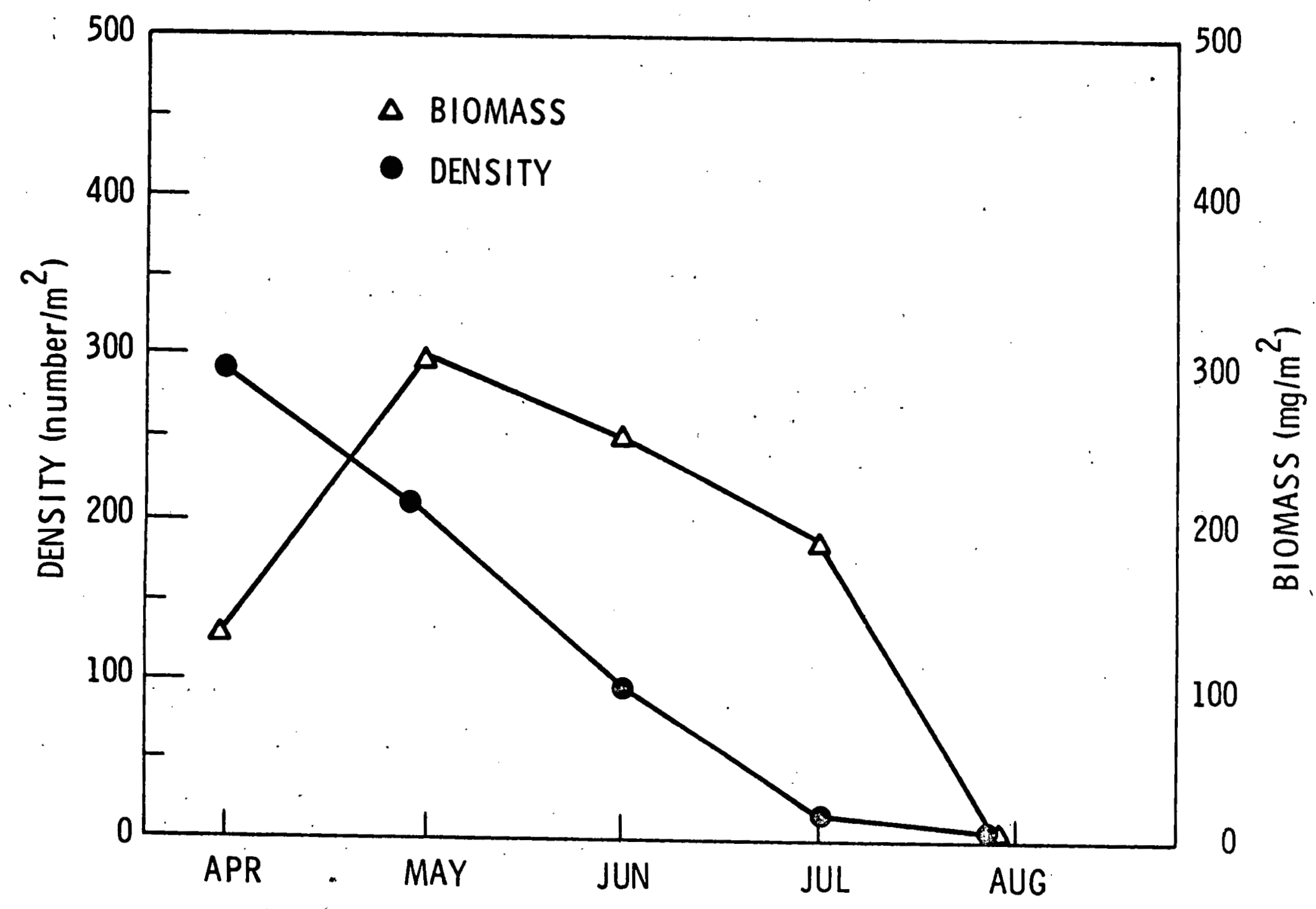




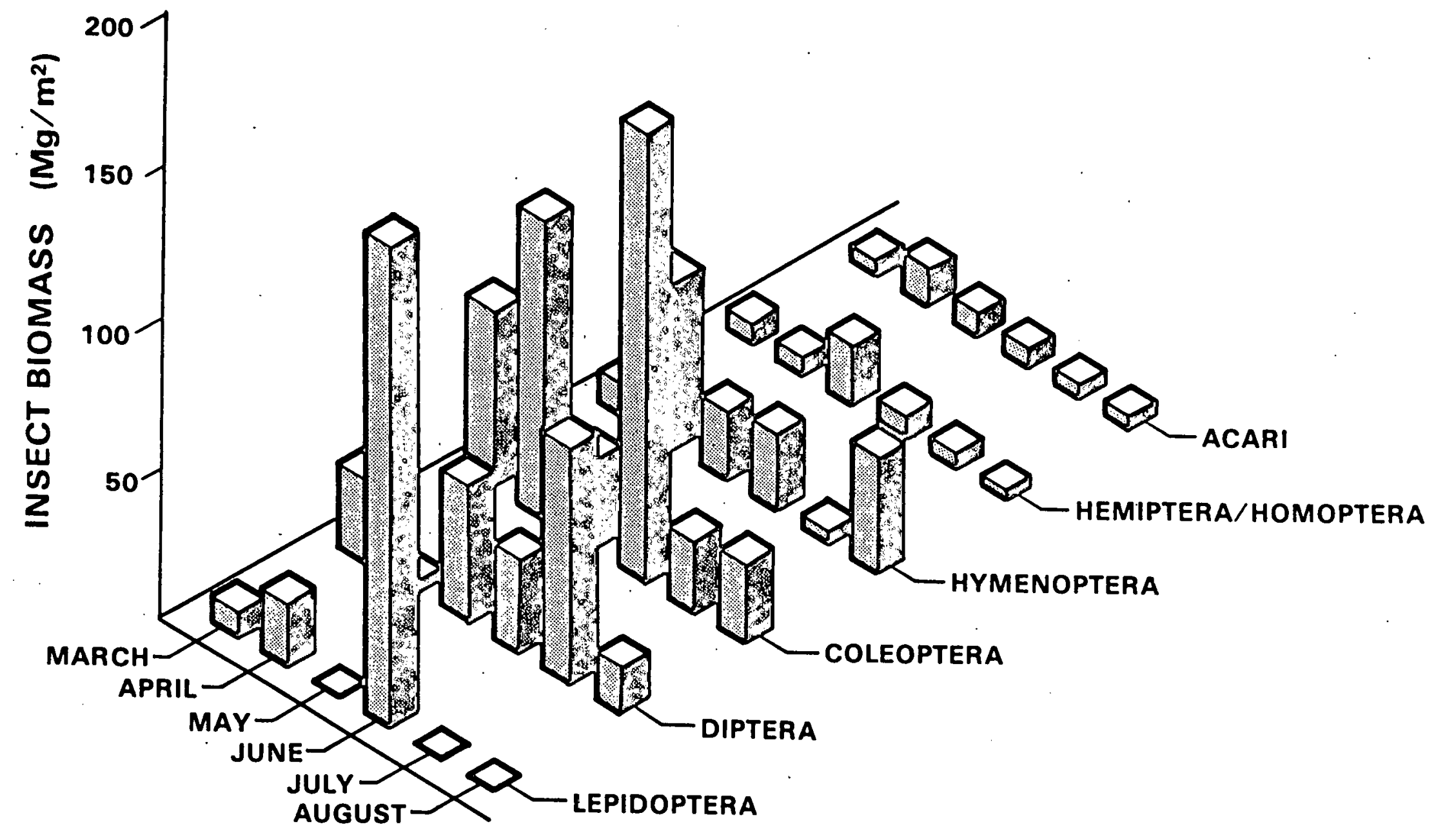




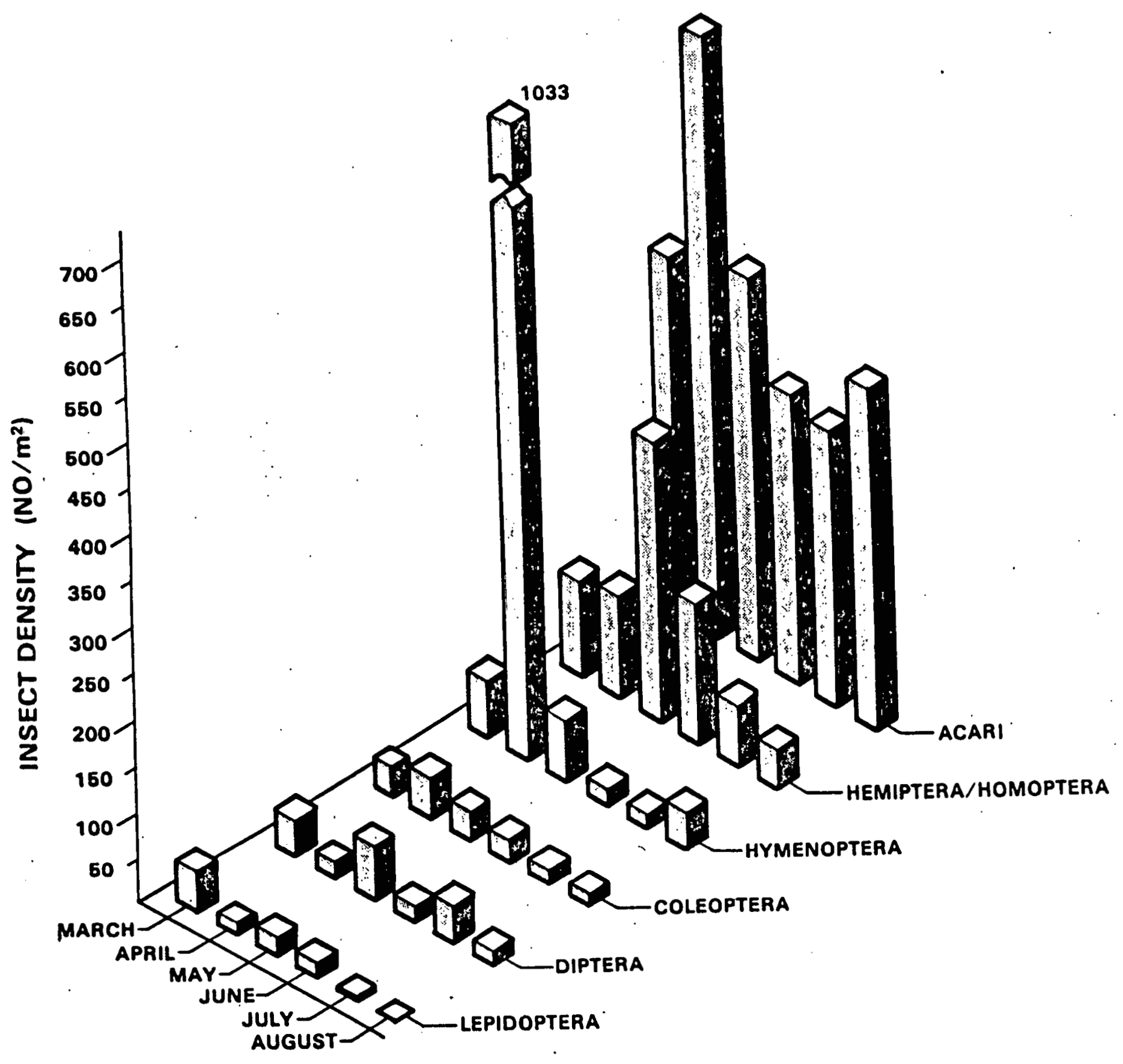

